Cali, B.B. and J.W. Moyer. 1981. Purification, serology, and particle morphology of two russet crack strains of sweet potato feathery mottle virus. Phytopathology 71:302-305.

Clark, C.A. and J.W. Moyer. 1988. Compendium of sweetpotato diseases. APS Press, Minneapolis.

Dangler, J.M., R.W. Scheuerman, R.N. Campbell, and C.A. Clark. 1994. Meristem-tip culture and California's clean foundation sweetpotato program. HortTechnology 4(3):227-228.

Fordham, R. and A.G. Biggs. 1985. Principles of vegetablecrop production. Population studies and propagation methods. William Collins Sons and Co., London. p. 68-70.

Hammond, D. and R.H. Daines. 1974. A virus in Centennial sweet potatoes as the agent of russet crack and internal cork. Proc. Amer. Phytopath. Soc. 1:150. (Abstr.)

Jester, W.R., C.W. Averre and J.R. Schultheis. 1994. Russet crack-like symptoms in Beauregard sweetpotato reduced by virus indexing and micropropagation. HortScience 29:727. (Abstr.)

Martin, W.J. 1970. The reproduction of russet crack in Jersey Orange sweet potatoes by grafting on plants affects with either sweet potato virus leaf spot or internal cork. Phytopathology 60:1302. (Abstr.)

North Carolina Crop Improvement Association. 1990. North Carolina certification handbook. Raleigh.

North Carolina Department of Agriculture. 1993. Marketing North Carolina sweetpotatoes including California, and Louisiana, 1992-93 crop. Division of Marketing. Dec.

Schultheis, J.R. 1994. Virus-freemicropropagated plants and clone effects on sweetpotato yield. HortScience. 28:727. (Abstr.)

Schultheis, J.R., W.W. Collins, and C.W. Averre 1994. Micropropagation, a means to enhance sweetpotato yield and quality. HortScience. 29:466. (Abstr.)

U.S. Department of Agriculture. 1963. United States standards for grades of sweetpotatoes. USDAMktg. Serv., Washington, D.C.

Wilson, L.G., C.W. Averre, J.V. Baird, E.O. Beasley, A.R. Bonanno, E.A. Estes, and K.A. Sorensen. 1989. Growing and marketing quality sweetpotatoes. North Carolina Coop. Ext. Serv. Bul. AG-09.

\section{Foundation Sweetpotato Seed Program in Virginia}

\author{
S.B. Sterrett and \\ C.P. Savage, Jr.
}

Additional index words. Ipomoea batatas,

sectorial chimera

Summary. A procedure is described for maintaining root quality in a foundation seed program that serves a primarily processing industry. Trueness-to-cultivar root type and color is maintained through hill selections within the prefoundation seed at harvest. Internal color is examined after sprout production, but prior to planting. Each root of the prefoundation seed is lifted and cut. If any sectorial chimeras are visible or the internal color is lighter than expected for that cultivar, all sprouts from that root are discarded. Otherwise, sprouts are planted to generate prefoundation seed. Prefoundation roots not selected by hill selection are given to designated growers for production of foundation seed. Contracts with growers for foundation seed and seed distribution are the responsibility of the Virginia Orop Improvement Assn. (P.O. Box 78, Mt. Holly, VA 22524). Hill selection of 'Hayman', a white-skinned, white-fleshed cultivar, over the past 20 years has essentially eliminated strings and nonenlarged roots. Improved root shape and smoothness has resulted in increased regional consumer demand for this specialty crop.

Eastern Shore Agricultural Research and Extension Center, Virginia Polytechnic Institute and State University, Painter, VA 23420.

These studies were supported, in part, by the Virginia Sweet Potato Board, Onley, Va. The cost of publishing this paper was defrayed in part by the payment of page charges. Under postal regulations, this paper therefore must be hereby marked advertisement solely to indicate this fact.

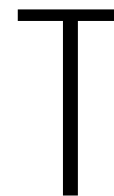

he sweetpotato foundation seed program in Virginia, like the industry it serves, is small, but focused, on maintenance or improvement of root quality. Because the majority of the orange-fleshed sweetpotato crop in Virginia is processed, the availability of "seed" roots with uniform, consistent internal color, free of chimeras or color breaks, is considered critical by Virginia growers. Most of the crop is harvested mechanically, graded primarily to remove roots with insect damage, and shipped field-run to the processor.

The management demands of producing sprouts combined with the declining availability of labor has madepurchased southern-grown sprouts an attractive alternative until recently. Now, increased transportation costs for sprouts, along with dockage for light, off-color roots at harvest, haveencouraged Virginiagrowers to producemore sprouts locally using Virginia foundation seed. 'Beauregard' is currently theprimary orange-fleshed cultivar in the foundation seed program, although 'Jewel' is also maintained in very limited quantities.

For the foundation seed program, prefoundation seed are maintained at the Eastern Shore Agricultural Research and Extension Center, Painter, Va. At harvest, hill selections are made within each cultivar using the procedure described by Watts (1956). All rows of a given cultivar are dug with aturn plow and scratched out, keeping all roots of the samehill together on top of the plowed furrow. The criteria for hill selection include trueness to root type and external color, root yield, uniformity, earliness, and number of roots set per hill. These roots are designated select roots and sprouts from these roots are used to produce the next generation of select and prefoundation seed.

After the hill selections for select roots have been made, the remainder of the small roots [ 1 to 2.5 inches or $(2.5$ to $6.3 \mathrm{~cm})$ ] are classified as prefoundation roots and, the following spring, are given to thegrower contracted by the VirginiaCrop Improvement Assn. for the production of foundation roots. When sprouts from the select roots are ready for planting, roots are lifted carefully from the beds, keeping all sprouts attached to their respective root. Each root is cut in transverse sections $\approx 1 \mathrm{~cm}(0.5$ inch) thick to check for acceptable internal color and freedom from sectorial chimeras (Fig. 1). If any sectorial chimera tissueis visiblewithin the select root, or theoverall flesh color is less than acceptable, then all the sprouts from that root are discarded. All sprouts that can not be identified with the corresponding mother root are also discarded.

Sectorial chimeras may vary in shape from prominent wedges to narrow streaks of light tissue. In a 3-year study, the annual mutation rate of 'Jewel' varied from $33 \%$ to $40 \%$ of the roots cut. The size of the sectorial chimeras appeared to be reduced by annual cutting and evaluation of the select roots when sprouts were pulled for planting 


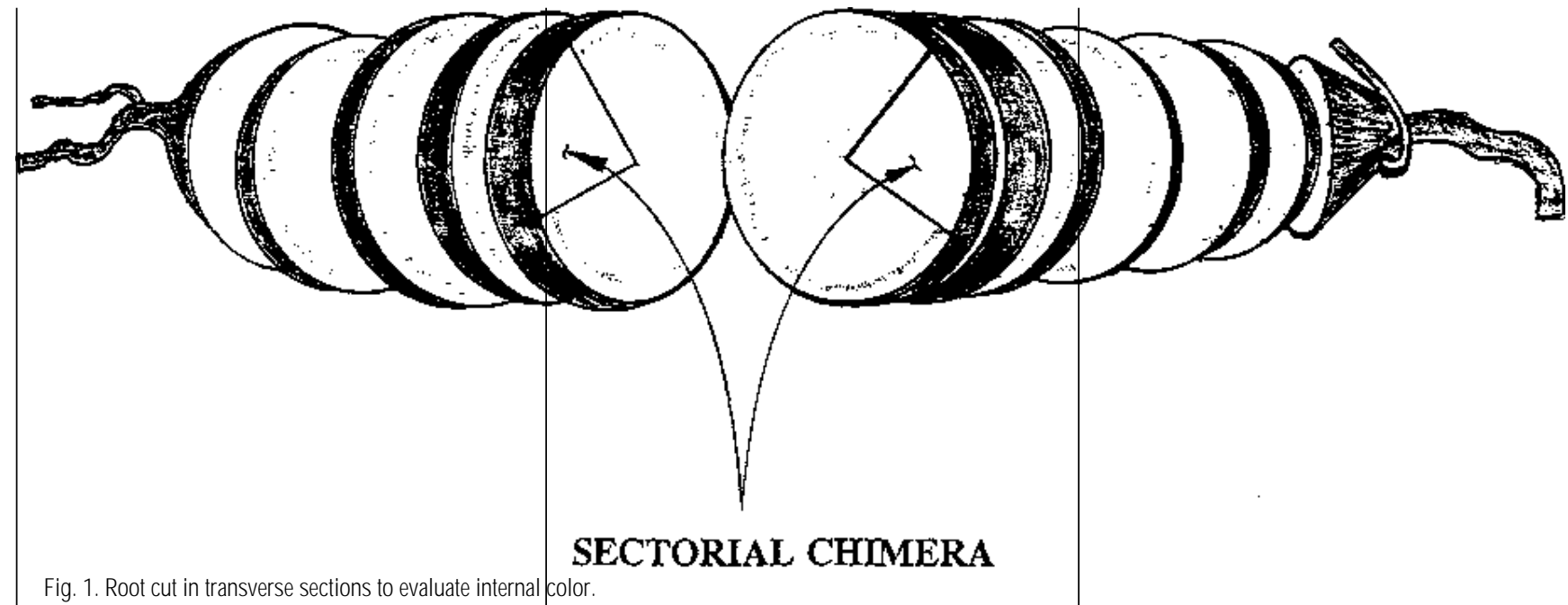

(S.B. Sterrett and M.R. Hall, unpublished data).

During the production of foundation or certified roots, three inspections arecompleted by the Virginia Crop Improvement Assn. for presence of black rot, stem rot, scurf, or varietal mixture, which would result in rejection. Although sweetpotato weevil has not yet been observed in this growing area, vigilancefor this insect pest is maintained by growers and inspectors.

For a field to be eligible for certification as either foundation or certified seed, no sweetpotato crop or potato residue can be applied to the field within the past 3 years. Each cultivar from each grower, including prefoundation roots, must be submitted for internal cork analyses each winter. Certified seed or plants shall not be more than two generations removed from foundation seed.

There are some sweetpotatoes grown for niche markets in Virginia. Of these, the greatest demand has been for foundation seed of 'Hayman', while limited quantities of 'Baker' are also sold annually. Historically, the white-skinned, whitefleshed 'Hayman' has been grown on the Eastern Shore only for local consumption, but the demand for 'Hayman' in other parts of Virginia is increasing. Often, the yield of marketable roots was half that of the yellow- or orange-fleshed cultivars, so that the cost of production was not offset by slightly higher prices for 'Hayman'. The origin of 'Hayman' is unclear, but growers in the Eastern Shore of Virginia and, to some extent, eastern North Carolina, have grown 'Hayman' for years with roots passed down from generation to generation. Long, stringy, unenlarged roots were a common occurrenceand detracted from thepacked product (Fig. 2a).

In the late 1970s, a commitment was made by the Virginiafoundation seed program to pursue improved yield and root uniformity of 'Hayman' by hill selection. Because of this effort, 'Hayman' roots distributed currently through the foundation seed program are shorter, smoother, more blocky, and relatively free of unenlarged roots or strings (Fig. 2b). In a replicated yield trial harvested 98 days after planting in 1992, marketable yield of hill-selected 'Hayman' was $64 \%$ of 'Jewel' (S.B. Sterrett and C.P. Savage, Jr., unpublished data). Because root sizing of 'Hayman' is slower than that

of 'Jewel', 'Hayman' is grown commercially 14 to 21 days longer, and the lower yield of 'Hayman' was expected. Root shape, earliness, root length-

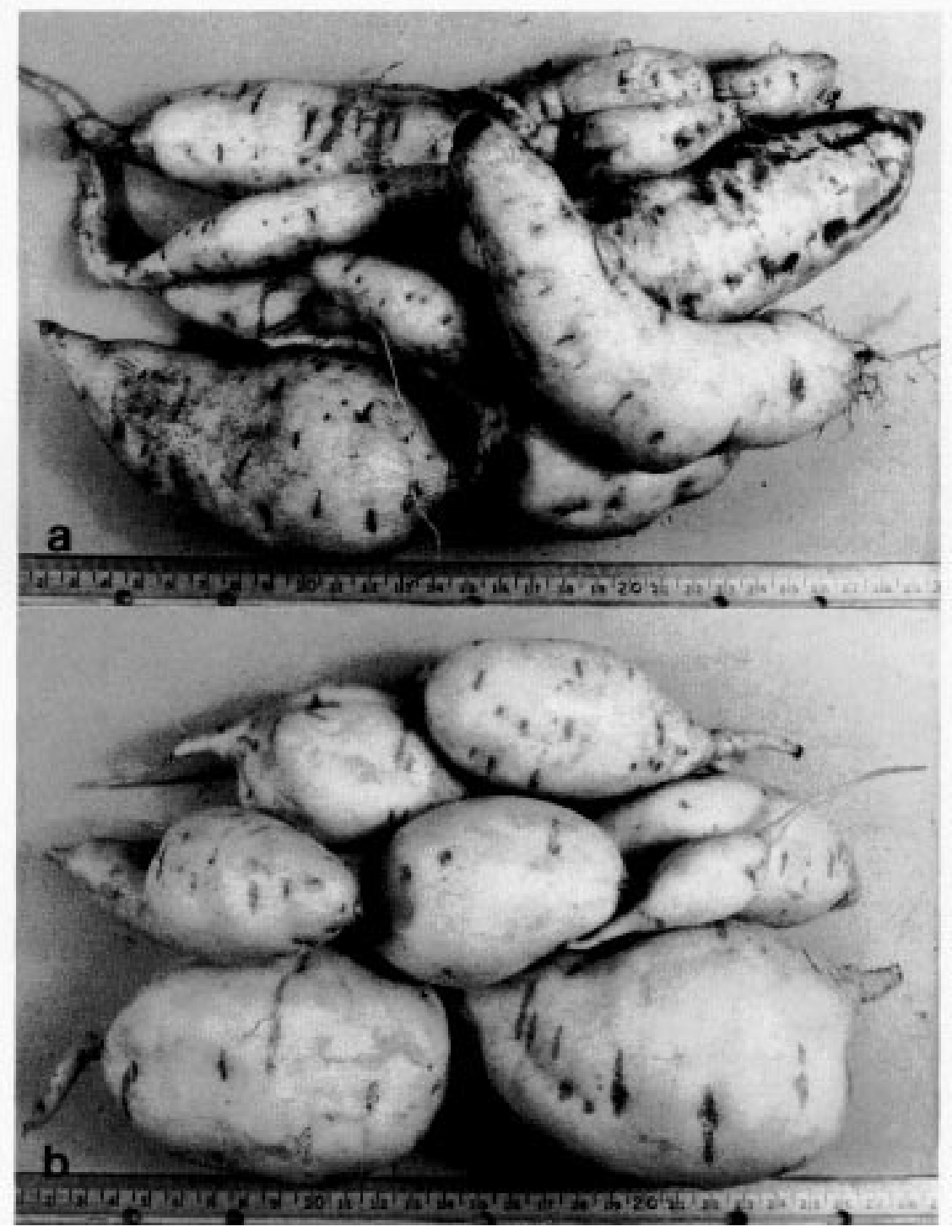

Fig. 2. (a) 'Hayman' roots obtained from local grower; (b) 'Hayman' roots after 15 years of hill selections. 
to-diameter ratio, and number of roots set per hill continue to be selection criteria for 'Hayman'. Sprouts from 'Hayman' select roots are planted without cutting the roots for the production of prefoundatoin seed because the internal flesh is white. Demand for foundation seed of 'Hayman' has increased from 10 bushels in 1985 to $>100$ bushels expected for 1995.

The cultivar Baker was released by the Virginia Truck Station for its superior baking quality, even when uncured (Nugent, 1969), and is grown for sale at roadside markets. 'Painter' and 'Shore
Gold', released by the Research Center (Graves, 1976; Sterrett et al. 1987, respectively), are maintained in small quantities using the same evaluation procedure. 'Jewel' is maintained by this procedure primarily to provide sprouts needed by our faculty for research purposes.

Orders for foundation roots of 'Beauregard', 'Baker', or 'Hayman' can be placed with Bruce Beahm, VirginiaCrop Improvement Assn., Box 78, Mount Holly, VA 22524. The available seed is apportioned according to supply and demand.

\section{Literature Cited}

Graves, B. 1976. Painter-A new sweetpotato variety. The Veg. Growers News 30(11):1, 4.

Nugent, T.J. 1969. Baker-A new sweetpotato variety. The Veg. Growers News 23(7):1-2.

Sterrett, S.B., B. Graves, C.P. Savage, Jr., and F.W. Coales. 1987.'ShoreGold'Sweetpotato. HortScience 22:332-333.

Watts, A.V. 1956. Hill selecting sweetpotato seed. The Veg. Growers News 11(3):2. 